Secondary publication on the edoc server of the Humboldt-Universität zu Berlin

https://doi.org/10.18452/21578

First published as:

Frank Hüesker and Timothy Moss: The politics of multi-scalar action in river basin management: Implementing the EU Water Framework Directive (WFD). Land Use Policy

2015, 42 (January), pp.38-47. https://doi.org/10.1016/j.landusepol.2014.07.003

This accepted manuscript version of the article stated above is licensed under a Creative Commons Attribution-NonCommercial-NoDerivatives 4.0 International License (CC BY-NCND 4.0) https://creativecommons.org/licenses/by-nc-nd/4.0/

\title{
The politics of multi-scalar action in river basin management: Implementing the EU Water Framework Directive (WFD)
}

\author{
Frank Hüesker and Timothy Moss \\ IRS Erkner, Germany
}

\begin{abstract}
Scholars of environmental governance are increasingly intrigued by issues of scale. Efforts to institutionalise river basin management represent a pertinent exemplar, as they aspire to strengthen hydrological vis-à-vis political-administrative scales of governance. The EU Water Framework Directive (WFD) is one of the most ambitious policy initiatives worldwide to reconfigure water management planning around the hydrological scale of river basins. Whilst it is widely assumed that the WFD is rescaling water governance in Europe, few empirical studies have been conducted to ascertain how far this is the case, what scalar strategies and practices are emerging and to what effect. The paper addresses these open issues with a study analysing the multi-scalar actions of water authorities, water management organisations, local authorities and interest groups involved in implementing the WFD. It investigates how stakeholders are acting scalar from the local to the European scale and back to further their interests in the course of WFD implementation, focussing on the Wupper sub-basin in Germany. Drawing for conceptual insight on the human geography debate on the politics of scale and processes of rescaling, we demonstrate how all relevant stakeholders are increasingly working across scales to advance their interests but in very different ways, with different degrees of deliberation and to different effect. A typology of multi-scalar action is developed to interpret this diversity. The paper draws conclusions on how multi-scalar action is altering not only power relations between the actors but also the scalar configurations themselves.
\end{abstract}

Keywords: River basin management; Water Framework Directive; politics of scale 


\section{Introduction}

The Water Framework Directive of the European Union (WFD) has become a showcase for new modes of environmental governance (e.g. Kaika and Page, 2003; Moss, 2004; Kastens and Newig, 2007; Woods, 2008). One of the most pertinent issues attracting increasing interest in policy and research circles is how the WFD has set in motion a process of reconfiguring the scalar organisation of water management (Thiel, 2009; 2010; Moss and Newig, 2010; Johnson, 2012). On the one hand, the WFD requires water management planning to be conducted around the scale of the river basin, alongside the scale of politicaladministrative jurisdictions (Art. 3). On the other, it is reordering the vertical decision-making process of water management in Europe, primarily by strengthening the role of the European Commission, now equipped with powers to monitor the achievement of wide-ranging environmental objectives for water quality according to a set timeframe and to sanction nonimplementation. This process of scalar reconfiguration is particularly dynamic by virtue of the new opportunities for the participation of stakeholders in the water management planning process created by the WFD.

Whilst it is widely assumed that the WFD is thereby rescaling water governance in Europe, empirically grounded knowledge on this phenomenon is limited. Individual studies have addressed the WFD as a new form of scalar governance in the EU as a whole (Johnson, 2012), in the Netherlands (Huitema and Bressers, 2006) and in Portugal (Thiel, 2009). Whilst these early scalar perspectives on the WFD have brought important new insight into the relative importance of river basin and jurisdictional scales in the implementation process, what is largely missing is an in-depth understanding of how key stakeholders are acting across scales in practice, how these actions are shaping scalar reconfigurations and what impact they are having on the ability of different actors to influence water policy. This paper investigates the practices and perceptions of key actors from multiple scales to assess how they are responding to the rescaling of water governance initiated by the WFD and what multi-scalar strategies and practices they are pursuing. Focussing in from the EU to one small sub-basin in Germany, these actors range from the European Commission and European lobby groups, via federal bodies and state agencies in North-Rhine Westphalia to a catchment-based water board - the Wupperverband - and local authorities and stakeholder groups in the catchment of the River Wupper. The paper targets multi-scalar strategies and practices (collectively termed 'scalar actions') specifically on the understanding that new scalar interactions in European water management are not predetermined in the text of the WFD and subsequent national legislation, but are to a large extent the product of an ongoing process of negotiation, collaboration and contestation. Our working hypothesis is that, in the wake of the WFD, some actors are advancing their water management interests by working across different spatial scales and that some of these actors may be pursuing a deliberate strategy of multi-scalar intervention. By operating in this way these actors, we claim, are not simply using existing spatial scales to their own advantage but, in doing so, are altering the political significance of some scales in relation to others and generating new modes of multi-scalar action with important implications for water policy outcomes.

Conceptually framed by recent research in human geography on the politics of scale and processes of rescaling relating to environmental governance, the paper investigates the multiscalar actions of the above actors to answer the following questions:

- Firstly, how far and in what ways are certain actors operating across and within river basin and political-administrative scales in implementing the WFD? 
- Secondly, how are these scales being constructed or reconfigured by these activities and around what key issues of WFD implementation?

- Thirdly, what effects are multi-scalar strategies and practices having on the power of actors to influence WFD implementation?

The paper is based on a literature review of the human geography literature on scale/rescaling pertinent to environmental governance, on documentary material on implementing the WFD in Germany and the Wupper sub-basin and on 15 interviews conducted with representatives from all the relevant scales between 2010 and 2012. ${ }^{1}$ In addition, the researchers organised three workshops with leading representatives of the Wupperverband and participated in internal meetings and in the annual river basin symposia (documented at www.wupperverband.de (accessed 31 May 2013)).

\section{Theory: Conceptualising Scalar Strategies and Practices}

In order to explore the process of scalar reconfiguration of water governance in the EU set in motion by the WFD it is important to develop first a clear conceptualization of what is meant by scale, processes of re-scaling and multi-scalar actions. Contributions to scalar concepts have emerged over the past 30 years within different streams of literature, which may be subsumed under the headings (1) human geography, (2) multi-level governance, (3) participatory governance and (4) environmental institutions (Jager et al. forthcoming). The following paper focusses on the human geography debate because it is particularly suited to guide conceptually our interest in the dynamics and politics of scalar action.

The human geography literature on the "politics of scale" explores the societal production and effects of spatial scales with a particular interest in revealing and explaining the shifting geographies of power relations (Smith, 2008 [1984]; Swyngedouw, 1997; Schmid, 2003; Brenner, 2004). In this literature scales are not taken as given, but as dynamic constructs. They are produced, structured and given value by actors in a continuous process of negotiation and contestation. This process of "rescaling" applies not merely to the structuration of single scales, but primarily to the reordering of relations between scales (Agnew, 1997, p.100). Of particular relevance to our paper, this approach to scale has recently been applied to human-nature relations. The interest here lies not only in exploring how the reorganisation of spatial scales is linked to control over natural resources (Swyngedouw, 2010), but also how rescaling works at the interface between traditional territorial scales and emergent scales of environmental governance (Bulkeley, 2005), such as for river basin management. These two scalar domains are regarded not as distinct entities, but as mutually constitutive. Thus, a new river basin organisation is a manifestation of reordered social relations, yet shapes these in return, as Swyngedouw has demonstrated for water policy under the Franco regime (2007). This insight on scalar structuration guides our response to the second research question of this paper.

Being at the same time product and medium of social production, scales are - for human geographers - key to understanding power relations. They are the "outcome of socio-spatial processes that regulate and organise social power relations" (Swyngedouw, 2010, p.12). More specifically, scales "enabl[e] particular relationships of power and space that advantage some social groups and disadvantage others" (Jones, 1998, p.28). The production and reorganisation

\footnotetext{
${ }^{1}$ The paper draws on findings from a research project funded by the German Research Council entitled RescalE (Rescaling Environmental Governance in Europe - The Water Framework Directive and the Spatial Organisation of Resource Regulation). Further information available at http://www.waterscale.info/project.html.
} 
of scales is conceived as an inherently political process because it entails the redistribution of power. Here, power is understood not as some attribute of individual actors, but as a product of social interactions. This coincides with modern, relational understandings in political science, whereby power is conceived as "the production, in and through social relations, of effects that shape the capacities of actors to determine their circumstances and fate" (Barnett and Duvall, 2005, p.42). In addressing the third research question of this paper we follow this general approach. We are interested in revealing who is gaining, and who is losing, power as a result of rescaling processes in water management in terms of the power to influence policy contents and the power of one actor over others (ibid., p.46), encompassing both indirect forms of power ("power as context-shaping") and direct forms of power ("power as conductshaping") (Hay, 1997, p.51). Our understanding of power includes the influence of so-called non-decisions (Nohlen, 1995, p.306), i.e. the ability of an actor to prevent political decisions it opposes.

If rescaling processes are about actors struggling to consolidate or strengthen their own position, how do they act scalar to this end? The human geography literature also provides guidance for this, our first research question. It notes, first of all, that the ability to act on multiple scales is not equally distributed and therefore itself an expression of power relations. Within these constraints some actors concentrate their efforts on preserving or gaining influence on one specific scale. In other cases multi-scalar strategies are pursued, whereby actors are active on several scales in order to maximise their influence (Brenner, 2001; Uitermark, 2002; Adger et al., 2005). One such strategy is scale jumping, by which "[p]olitical claims and power established at one geographical scale are expanded to another" (Smith, 2000, p.726; cf. for environmental governance, Köhler, 2008). This resonates with the phenomenon of "venue shopping" identified in political science (Baumgartner and Jones, 1993). Another practice is scalar bypassing, in which an actor deliberately leapfrogs the hierarchical order. In this paper we develop and apply a wider range of terms to reflect the specifics of scalar politics in environmental governance. For analytical purposes we need to distinguish between hydrological scales (ranging from a small sub-catchment to a major transnational river basin) and jurisdictional scales (ranging from a local authority to the European Union) as a precursor to explaining their interdependence. We therefore talk of cross-scalar action when referring to interplay between river basin and political-administrative scales and to intra-scalar action when addressing multi-scalar activity within one of these domains. Finally, we distinguish between multi-scalar strategies, when specific actors purposefully seek to increase their influence over water management by means of acting across multiple scales, and multi-scalar practices, when acting across scales is not part of a deliberate strategy to strengthen their power base but is a reactive or contingent response to circumstances. We identified intentionality behind multi-scalar action by analysing statements made by the key actors in interviews, meetings and policy documents.

Water management lends itself particularly well to a study of scalar action. As water resources are regulated across diverse political-administrative and hydrological scales, their management represents a good empirical example of the challenges posed by multi-scalar governance (Blomquist et. al., 2004; Lebel et al., 2005; Dore and Lebel, 2010; Reed and Bruyneel, 2010; Norman et al., 2012; Herrfahrdt-Pähle, 2014). Attempts across the globe to institutionalise river basins and their sub-units as the prime scalar units for water resources management are far more advanced than comparable initiatives to orientate other environmental policies, such as habitat management or marine planning, around "natural" scales. As probably the most ambitious initiative of this kind worldwide, the WFD and its implementation represent an ideal object for the study of rescaling processes (Huitema and Bressers, 2006; Thiel, 2009; Johnson, 2012). In this paper we contribute to existing knowledge on scale and the WFD firstly by applying human geography concepts of rescaling 
and the politics of scale to empirical analysis, secondly, by analysing multi-scalar strategies and practices with a case study of diverse actors implementing the WFD in a sub-basin in Germany and, thirdly, by reflecting on how these strategies and practices are influencing power relations and scalar reconfigurations in water management.

\section{Analysis: Acting scalar from Brussels to Wuppertal and back}

The WFD is a truly ambitious initiative of EU environmental policy, aiming at achieving "good water status" in European surface water bodies by 2015 (EC, 2000). As one core instrument to meet this objective, the river basin has been prescribed as the principal scalar dimension for water management within the EU. This spatial reorientation of water management planning along ecological systems instead of political boundaries is pursued in order to enhance effectiveness of policy implementation (Newig and Fritsch, 2009). In addition to elevating the river basin as the prime scalar unit for water management planning, political authority and decision-making capacities have also been reconfigured between European, national, regional and local scales (e.g. Kaika and Page, 2003; cf. Gualini, 2006; Heeg, 2008). The WFD calls for "the active involvement of all interested parties in [...] implementation" (Article 14). This involvement refers to the elaboration of river basin management plans and programmes of measures, which have to be passed every six years in order to specify the concrete steps to implement the WFD. It highlights the importance of considering non-state actors when investigating multi-scalar practices and strategies.

Both the strengthening of the river basin scale as well as the opening up of policy processes to participation can, themselves, be seen as an expression of a novel multi-scalar strategy of the European Commission. More significantly, though, these reforms are generating new structures and procedures for cross- and intra-scalar negotiation and collaboration in implementing the WFD. These, in turn, are creating opportunities for new, more intensive scalar actions by key actors and thereby reordering power relations, in which some actors stand to gain and others to lose influence. This section investigates the multi-scalar practices and strategies of six groups of actors, identified and classified from the documentary material and interviews. These groups comprise the European Commission, EU interest groups, German federal and state governments, the state of North-Rhine Westphalia, the water board Wupperverband and local stakeholders in the Wupper sub-basin (see Fig. 1). Whilst fully aware of the huge diversity between these actors in terms of their water management responsibilities and power resources, we seek to explore and explain the ways in which they are acting multi-scalar in implementing the WFD and how this is changing their ability to influence water management planning. Since the WFD does not alter the formal responsibilities for water management we are particularly interested in revealing how each actor group is using its available resources to act multi-scalar in pursuit of its interests within the new policy framework.

\section{[Insert Fig.1 about here]}

Figure 1: Location of the Wupper sub-basin in Germany

Source: own compilation 


\subsection{The European Commission's multi-scalar actions}

The Directorate General for Environment of the European Commission (DG ENV) is the actor responsible for EU water policy. Within this Directorate General the Water Unit is in charge of implementing the WFD. The institutionalisation of the river basin scale for the spatial organisation of water management in the EU (Art. 3) can be viewed as the point of departure for a new multi-scalar strategy by the European Commission and a key instrument for pursuing the WFD's environmental objectives of good ecological quality for surface waters. Rather than require all Member States to set up new river basin authorities, DG ENV is content with the compromise solution for each Member State to determine a competent authority for each river basin district, even if - as in the case of Germany - this is a body responsible for a political-administrative jurisdiction, such as a state environment ministry (interview DG ENV). DG ENV sees this merely as a first step towards a constructive rescaling process in which - out of necessity - Member States will increasingly recognise the need to orientate water governance around river basins and their sub-units. Following this scalar strategy the important innovation is to have a body legally required to institutionalise river basin management and to formalise a number of structures, instruments and procedures (such as the river basin management plans, programmes of measures and reporting procedures) which are oriented around river basins. The second step according to this scalar strategy will be to promote a rebalancing of power between existing and new, river-basin oriented institutions in the course of a learning process. The expectation or hope is that traditional sectoral and territorial organisations will in the long run lose influence to emergent governance forms on the river basin scale (interview DG ENV). This strategy can be interpreted as deeply multi-scalar in the sense that it is both cross- and intra-scalar and very deliberate. It enables DG ENV in the course of implementing the WFD to develop its power base via networking, forming alliances, gathering data, defining aims and principles etc. not only between European and national jurisdictions, but also between the Commission and organisations structured around river basins.

At the same time, DG ENV is pursuing a strategy of strict adherence to implementation of the WFD's ambitious environmental objectives and reporting procedures. The Water Unit, although equipped with only a handful of employees, is using its position of overall authority at the top of the scalar hierarchy to put pressure on the Member States - and, by extension, all subordinate actors, whether on jurisdictional or river basin scales - to deliver results, data, management plans and programmes of measures to Brussels on time (interviews DG ENV, EU agriculture, EU water utility, Lower Saxony). One frequently cited example of this multiscalar strategy of playing the 'tough guy' is the Commission's publication of a large number of infringements and cases of non-compliance in the Water Blueprint of EU water policy (European Commission, 2012). This strategy is widely criticised for being insensitive to the early stage of the WFD implementation process, given that much data on water quality has not yet been collected and the river basin management plans and the programmes of measures are just starting to have an impact. More seriously, it threatens to backfire by alienating those actors on lower scales on whose support the Commission depends for effective implementation measures (interviews EU agriculture, EU environment, Lower Saxony). From this perspective the European Commission is seen to be overstretching its authority and placing too much of a burden on the responsible actors on national and regional scales. If this criticism is correct, the strategy of the Commission could have negative consequences for European environmental policy. 


\subsection{EU interest groups' multi-scalar actions}

Non-state actors from the fields of agriculture, environment, water and business policy lobby for their interests in Brussels via national experts. In terms of scalar organisation the preferred setting is to have small offices in Brussels which are entrusted with following the daily political process of policy development in the European institutions and informing their national members. The scalar strategy of EU interest groups is to contact only the national and not the sub-national scale (interviews EU environment, EU agriculture, EU water utility). This is a limited scalar strategy which deliberately avoids scalar bypass.

In response to the WFD all the interest groups interviewed have recruited water experts at national and European scales (interviews EU environment, EU agriculture, EU water utility). This confers with the impression in DG ENV that the WFD implementation process has resulted in a growing number of interest groups lobbying the European Commission on waterrelated issues. Although often with only limited staff resources, these EU interest groups keep their national members up-to-date and lobby at the European scale (Deutscher Naturschutzring, 2012). An interesting illustration is the growing practice of some national environmental NGOs to inform DG ENV of possible infringements of the WFD in their own countries, encouraging the Commission to take remedial action (European Environmental Bureau, 2011; interview DG ENV).

There is a downside for the interest groups, however. The emergence of a multitude of new stakeholders, taskforces, networks, action groups etc. at the European scale in the wake of the WFD is overstretching the resources of some interest groups. The numerous new policy papers and assessments need to be digested in addition to the work of translating and communicating the Commission's communications for national members. Interviewees complain that, as a result, their effectiveness in lobbying is being compromised by the need to be excessively multi-scalar in their work. The EU lobby groups interviewed doubt that strategies to participate everywhere at the European level are having a positive impact on European water policy.

\subsection{German federal and state governments' multi-scalar actions}

In Germany, the WFD has not altered legal responsibility for water management. As a federal state, authority over water protection is divided between the federal government, responsible for framework legislation and for implementing the WFD nationally, and the 16 state governments, responsible for implementing the WFD in the 10 river basins in Germany (Moss, 2004). This places the federal government in a difficult scalar dilemma, caught between overall legal responsibility to the EU and reliance on the states for meeting the WFD's objectives. In terms of the relationship between jurisdictional and river basin scales, our interviewees at the state level concede that the WFD is challenging the traditional scalar configuration of German water policy around political-administrative units by virtue of the ambitious aims and strict deadlines set at the European level and a relatively open policy process on how to get there on river basin scales. Particularly in the initial phase of WFD implementation, up until the completion of the first planning period in 2009, there was, in the eyes of our interviewees, a veritable 'hype' around collaboration on river basin scales. Now that the process of implementing the plans with specific measures has begun, the state officials see a renaissance of traditional actors organised around political-administrative scales who have the means and the authority to implement these measures (interviews Hessen, Lower Saxony). They are, in effect, predicting resurgence in their own powers over water management planning - in stark contrast to the expectations of the European Commission described above. 
Central to the scalar actions of both federal and state water authorities is the growing need for them to speak with one voice to the European Commission. The principal forum for developing a common position on WFD implementation in Germany is the Working Group of the Federal States on Water Problems (LAWA) (Kastens and Newig, 2007). Its original membership of the environment ministries from all 16 states was extended in 2002 to include the Federal Environment Ministry (responsible for water) in order to improve and strengthen harmonization of WFD implementation between the state and federal scales. LAWA has thereby become an intra-scalar organization in our terminology. The coordination and development of joint implementation measures is now one of the principal tasks of LAWA (LAWA, 2010). By developing harmonised standards (e.g. for water quality in specific river types) federal and state agencies hope not only to justify European water policy to their citizens more coherently but also to strengthen their combined power vis-à-vis the European Commission in the WFD implementation process (interviews Hessen, Lower Saxony). To clarify scalar responsibilities an agreement was reached in 2010 - in the so-called 'Frauenchiemsee Paper' - which distinguishes between those river basin management topics where the federal level is responsible (under the influence of LAWA) and those to be addressed at the river basin scale (under the influence of individual states). For example, the definition of environmental quality norms (physical or chemical) lies within the remit of LAWA, whereas the right to take action to implement these norms is located on the state level (LAWA, 2010).

In dealings with EU institutions (e.g. Common Implementation Strategy - CIS - groups) the Federal Environment Ministry acts on behalf of Germany in co-ordination with the federal states via LAWA (LAWA, 2010). The common practice is for a state representative from LAWA to accompany the federal representative to meetings at the European level (interview Lower Saxony). Representatives of the German federal states are also involved in different working groups at the European level directly (e.g. EUnet, former EU Working Group). The issue of data aggregation and reporting provides a good illustration of the division of multiscalar action between the federal and state levels (LAWA, 2010). Here, the federal government is required to report data to Brussels, but the states were fearful of losing influence over water policy by having to transfer their data to Berlin first. The agreement reached is to distinguish between aggregated data from the sub-basin scale upwards which goes to the European Commission and aggregated data from below the sub-basin scale which is withheld by the individual states (interview Lower Saxony).

Aside from the new formal divisions of responsibility, a distinct learning process can be observed amongst state officials. In the beginning, German water administrators were generally sceptical, citing a lack of legitimacy and efficiency at the river basin scale. Today, many see the potential for achieving water policy objectives via the scalar reconfiguration set in motion by the WFD. Especially those pursuing innovative and integrated water policies who are active for Germany at the European level have gained significant influence in the course of implementing the WFD (interviews Hessen, Lower Saxony).

\subsection{Multi-scalar actions of the state of North-Rhine Westphalia}

Given the considerable powers of German states in implementing the WFD, the ways in which a state water authority interacts downwards with subordinate public authorities and simultaneously across hydrological scales is of great significance to the scalar politics of water management. This applies in particular to North-Rhine Westphalia (NRW), Germany's most populous state, responsible for implementing the WFD in the Wupper sub-basin (workshops Wupperverband, symposia Wupperverband 2011 and 2012). In NRW, water authority is exercised not only at the state scale via the Environment Ministry (MKUNLV) 
and its administrative arm (LANUV), but also at the scale of subordinate district governments (Bezirksregierungen). River basin management is implemented along a parallel scalar hierarchy, from (international) river basins, notably the Rhine, sub-basins, such as the Wupper, and then smaller subsidiary catchments. The problems of cross-scalar coordination are self-evident here. In the case of the Wupper the boundaries of political jurisdictions and river basins do not match at all: the Wupper sub-basin falls within the jurisdiction of four district governments (see Fig. 1). How do these state bodies deal with this scalar misfit in practice?

Our research suggests that the MKUNLV and NRW's district authorities employ a scalar strategy centred on leaving the daily business of implementing the WFD to the existing water boards already organised around river basins. The strategy of the state actors is to delegate modest powers to these water boards, which were established in this part of Germany from the late nineteenth century onwards. Being legally responsible for implementing the WFD in NRW, MKUNLV and the district authorities realize that ultimate power to make binding decisions remains in their hands. The district authorities of Düsseldorf and Cologne - both responsible for most parts of the Wupper sub-basin - still have to authorize most implementation measures at some stage and provide around $80 \%$ of the funding for ecological improvements, giving them considerable political leverage. This funding is, in turn, based on legislation and budgets approved by the NRW government. Similarly, the river basin management plans and programmes of measures are also decided by the NRW government and parliament (Bernhardt and Hüesker, in press, interview district government, workshops Wupperverband). The strategy can be characterised as cross-scalar in the sense that actors of political-administrative units are allowing actors on the river basin scale relative leeway to act on operational tasks, but by virtue of their significant decision-making and funding powers they exercise considerable influence over the WFD implementation process (interview LANUV). This scalar strategy is on the one hand a pragmatic division of labour and on the other an expression of experimental exploration in sub-basin governance whilst retaining overall control.

\subsection{The Wupperverband's multi-scalar actions}

Water management in the Wupper sub-basin has been the remit of the catchment-based water board Wupperverband for decades. This scalar configuration, with its strong tradition of river basin management, is unique to the water boards of NRW and makes for an interesting study of rescaling via the WFD. Originally founded in 1930, the Wupperverband, with a core membership of local authorities and industrial water users, is today responsible for a wide range of water management tasks, ranging from pollution control, wastewater treatment and reservoir management to, increasingly, river restoration (see www.wupperverband.de, accessed 31 May 2013). Across the Wupper sub-basin the water board operates 12 reservoirs, 11 sewage treatment plants as well as structures for flood retention, managing ca. 2,300 km of rivers and streams. As part of the WFD implementation process the Wupperverband organised round table workshops at the sub-basin scale on four occasions between 2008 and 2009. In addition, regional working groups have been established on the subordinate scale of three planning units within the sub-basin in order to devise implementation timetables for specific measures.

The first scalar strategy of the Wupperverband is to establish its position as the key actor for implementing the WFD in the sub-basin. This is pursued by proactively pushing for an ambitious interpretation of WFD implementation and enrolling the support of its members to this end. Although officially it is implementing the WFD on behalf of MKUNLV and the district authorities, in public the water board presents its actions as voluntary and the product 
of its own initiative. The Wupperverband has taken the lead in organising and facilitating the participatory processes to establish river basin management plans and programmes of measures in the catchment. The Wupperverband strategy is multi-scalar in that it enrols the local, river basin, district authority and state (NRW) scales in its work (symposia Wupperverband 2011 and 2012, workshops Wupperverband 2012). The Wupperverband takes advantage of the fact that its traditional spatial remit fits neatly to the institutionalisation of river basin management envisaged by the WFD. Given its pivotal scalar position between the sub-basin it manages and the political jurisdictions of its members, the Wupperverband has become the region's lead player in implementing the WFD. It sets procedural rules and the regional water policy agenda and organises collaborative ventures with local stakeholders (interviews county $1+2$, municipality, local stakeholders). Our fieldwork suggests that this is a successful example of a deliberate multi-scalar strategy to increase the water board's sphere of influence, especially over the water policy agenda.

A second multi-scalar strategy employed by the Wupperverband is to become a front-runner in developing problem-solving models on other scales. The Wupperverband is investing considerable resources in defining parameters to measure the ecological status of rivers, for instance with its own river-basin based Geographic Information System 'FluGGS' or with manageable data collection methods in the context of the intercalibration requirements. As a successful front-runner it hopes to be able to offer these models at a later stage to actors at other scales. The Wupperverband's CEO and head of unit responsible for GIS are both members of the GIS committee of the German Association for Water, Wastewater and Waste (DWA) and use their positions to promote the Wupperverband's models at the national scale (symposium Wupperverband 2012; workshops Wupperverband). They are banking on the assumption that actors on various scales will need this kind of expertise when the implementation of specific water protection measures becomes imminent and the risk of sanctions by the EU for non-fulfilment increases. Potential beneficiaries are local authorities confronted with the need to alter river structures, state ministries or other water boards with less experience in operative WFD implementation and interest groups seeking help in evaluating river basin management plans (interviews LANUV, county $1+2$, local stakeholders). Being a front-runner in such a process is an example of a potentially successful multi-scalar strategy, in which water management expertise is used as a vehicle for influencing WFD implementation in line with the water board's interests and for strengthening its position in relation to national implementation policy (upscale) and local stakeholders (downscale). However, the strategy is risky, in that it demands considerable financial resources, manpower and time with no guarantee of the board's models gaining wide acceptance ultimately.

\subsection{The multi-scalar actions of local authorities and interest groups in NRW}

The role of local authorities and interest groups in the WFD's implementation process is of particular interest given the Directive's explicit requirement for formal participation and the implicit dependence of the responsible authorities on stakeholders at large to help achieve its environmental objectives (Kastens and Newig, 2008). In the following we examine the scalar action of local authorities at both municipal and county levels and of interest groups in NRW representing environmental, water supply and agricultural interests.

Municipalities in the catchment, as members of the Wupperverband, all participated in the round table discussions on the river basin scale (workshops Wupperverband, interviews district government, county $1+2$ ). They all agreed to the WFD implementation scheme, including commitments for co-funding measures. This formal support for the implementation process, however, masks a generally reserved and calculating stance of most municipalities 
towards the WFD. They approve the steps proposed by the Wupperverband in the knowledge that, in the event of local criticism, they can always pin the blame on the water board, the district government or the EU. By delegating authority - via their membership - to the Wupperverband municipal leaders do not have to persuade their own city councils and assemblies to pay for expensive measures to implement the WFD, such as the removal of a weir. At the same time, local decision-makers know they ultimately remain the competent authority to decide over the removal of the weir with the power to delay decisions, as water board officials complain. By retaining a degree of influence in the later stages of the implementation process, municipalities can be regarded as fairly successful in acquiring power at the river basin scale while retaining influence at the local level. Their strategies are limited in scalar scope, though, as only large cities are able to intervene at scales above their own sub-basin or state (workshops Wupperverband, interviews district government, LANUV).

The seven counties (Landkreise) with territory in the Wupper sub-basin have become unwitting intermediary organisations between local groups and state or district authorities. From their perspective many municipal representatives attending the round table debates do not fully understand the implications of the WFD and its implementation (interviews county 1 +2 ). The counties find themselves, consequently, in a position of facilitating the implementation process between the state of NRW, the water board and local stakeholders, especially landowners who did not actively commit themselves to measures in the discussions. This new intra- and cross-scalar influence was not deliberately sought by the counties, but is now used by them to their own advantage (interviews county $1+2$ ).

Local interest groups were initially sceptical of participating in the round table discussions on the sub-basin scale and did so often only because they were invited. The initial purpose of attending was to ascertain whether the water board and state administration were planning anything likely to run counter to their interests. Over time, however, these local groups have come to appreciate that, in the case of the round table events organised by the Wupperverband, their interests are taken seriously and they are able to put issues on the agenda of the draft river basin management plans. It is widely felt that participating in fora at the sub-basin scale has been a novel and fruitful experience, permitting influence over regional water policy (interviews local water utility, local agricultural association, local environmental NGO). Many feel, however, that the most influential actors are those with more expertise and resources at their disposal, like the agricultural association of NRW and the water board itself. Interestingly, environmental NGOs, though very active in the participation process, are felt to have lost influence overall. Before the WFD they were consulted - if at all - bilaterally. Today, they need to make their voice heard amongst a plethora of other interest groups in the sub-basin (interviews local water utility, local agricultural association, local environmental NGO).

By contrast, agricultural stakeholders in NRW are proving a powerful actor in the WFD implementation process, pursuing very deliberate multi-scalar strategies and acting on hydrological as well as jurisdictional scales. In the knowledge that the ecological aims of the WFD to improve groundwater and surface water quality cannot be achieved effectively without the support of farmers, their lobby organisation, the chamber of agriculture (Landwirtschaftskammer, LWK), has developed two successful scalar strategies to gain influence over NRW's water policy. The first is to lobby at EU, national and state scales against aspects of WFD implementation deemed detrimental to farming interests. This involved, for instance, the LWK drafting a contract with the state ministry of agriculture which effectively guarantees that farmers in NRW will incur no economic disadvantages. LWK representatives are also members of DWA's committees involved in shaping national water quality standards. Regarding the status of heavily modified water bodies (HMWB), the 
water unit of LWK directly contacted DG ENV in Brussels to agree on a definition acceptable to farmers. It subsequently employed some 40 water policy advisors to check historical maps and visit every farm in NRW in order to prove which parts of the river were modified by human activities in the past, thereby increasing the number of watercourses termed heavily modified by one third (interview LWK). The second strategy has been to use the considerable expertise gained through its freshly employed water specialists to participate actively in the WFD implementation process at all stages and in all catchments. Whilst declaring its willingness to help achieve the WFD's environmental objectives, the LWK is exploring winwin measures capable of benefiting both the farmers' economic interests and water protection (interview LWK). Other local stakeholders and authorities acknowledge the success of this strategy. In our terms it is a successful example of the politics of scale, using the opportunities offered by the WFD implementation process to increase power over regional water policy. The strategy is particularly multi-scalar, as the chamber's representatives are paid and organized on the state scale whilst operating on the catchment scale.

\section{Interpretation: A Typology of Scalar Action}

Having described the multi-scalar strategies and practices of key actors, we now look across their scalar actions to make some general observations. By way of orientation we draw on our three research questions above relating to the kinds of scalar actions developed, the processes of scalar (re-)configuration and their impacts on power relations in implementing the WFD. The empirical findings have clearly demonstrated the inadequacy of a simple, binary distinction between scalar 'strategy' and scalar 'practice'. Although a few observed forms of scalar action are clearly strategic, in the sense of purposeful work across scales, most involve varying degrees of intentionality. In order to capture better the complexity and subtlety of scalar action observed, we present in the following section a typology developed inductively out of the empirical data. These types of scalar action are: engagement, enrolment, delegation, facilitation, harmonization, appropriation and acquiescence. For each of the seven types of scalar action we provide examples for illustration and reflect on the consequences for power constellations and rescaling processes in implementing the WFD. Although similarities between some of the types can be discerned, they each describe a distinct form of scalar action worth highlighting. Since they represent generic, rather than actor-specific, types the various scalar actions of one actor may be attributed to more than one category. We should reiterate that not all types of scalar action are open to all actors, whose options are limited by their scalar position, power relations and resources.

1. Engagement: The active involvement of actors across different scales.

The study reveals a number of actors who deliberately set out to advance their interests by actively engaging in negotiation processes on diverse scales. Examples include the lobbying of EU environmental NGOs on both national and European political scales (intra-scalar) and of local environmental NGOs by-passing their national governments in whistle-blowing to the European Commission. The agricultural chamber of NRW is active on all relevant scales in parallel, seeking to protect farmers' interests whilst ostensibly pursuing the aims of WFD. The advantage of these deliberate scalar strategies is the chance to increase influence over the water policy agenda at other scales. Our research suggests that non-state actors are more adept at cross-scalar networking and lobbying in

the WFD implementation process than public agencies. This can help open up old scalar configurations which restricted cross-scalar solutions in past environmental governance. Potential disadvantages we have observed are that these scalar strategies often rely on 
informal processes and contacts (e.g. to DG ENV staff), lack transparency and legitimacy and ultimately give preference to powerful actors.

2. Enrolment: Encouraging other actors to work across different scales.

Enrolment is about getting others to participate in implementing the WFD by working across different scales. One example is how the CIS groups encouraged various national or EU interest groups to be more active in river basin management - i.e. to act intra- and cross-scalar. Another is the strategy of the Wupperverband to organise the round table events as a way of enrolling initially sceptical local actors in river basin management planning. In the case of the Wupper it seems as if the scalar action of those involved many of whom had no previous experience of river basin management - is likely to bear fruit in the form of real improvements to water quality and substantive changes towards more collaborative water governance in the catchment. Enrolment can empower both the enrolling actor (e.g. Wupperverband) and those formerly passive actors. Conversely, enrolment might correlate with the disempowerment of formerly active actors who now need to compete for influence (e.g. local environmental groups). The enrolment of former veto-players might increase performance, but requires considerable resources and is often limited to the solution of easy tasks.

3. Delegation: Distributing tasks to other scales.

Rather than encouraging participation, delegation is about reordering scalar responsibilities. An obvious example is the strategy of the state government of NRW and its district governments to grant the Wupperverband the right to conduct initial operative tasks of WFD implementation but to retain legal authority over financing and authorising WFD measures in the long run. Similarly, local authorities have long delegated water management tasks to the Wupperverband for reasons of cost-effectiveness and of finding river basin-based solutions, but also to avoid direct responsibility to local electorates for expensive water policy measures. It would appear that delegation is an effective scalar strategy for public bodies, enabling them to accord specific powers for a limited time to other scales (e.g. river basin organisations) whilst retaining overall responsibility for financing, licensing etc.. Intra-scalar delegation is, of course, familiar action for administration officials on all scales researched. They, however, are very reluctant to consider scalar-bypassing or to undermine the scalar configuration of hierarchical jurisdictions. Their scalar action is generally reactive, rather than deliberate. Delegating political responsibility to other scales has the potential to raise the effectiveness and the acceptance of implementing the WFD, as the examples of the municipalities at the Wupper, the district authorities in NRW and also DG Environment suggest. It would appear to be part of the scalar strategic game to let the actors on hydrological scales implement policies which could not be implemented on the jurisdictional ones. However, legitimised actors on jursidictional scales, whether local or European, remain powerful and influential at a distance.

4. Facilitation: Creating or adapting existing procedures and structures to improve intraand/or cross-scalar action.

Reconfiguring institutional arrangements is a further scalar strategy observed. A key example is the way the European Commission, and DG ENV in particular, has introduced strict planning procedures, timelines, monitoring methods and sanctions in order to oblige Member States and their relevant agencies to pursue new water policy objectives in the context of river basin management. The reform of LAWA to include representatives of the federal government is a further example of intra-scalar facilitation, though of a less purposeful nature. Many actors see facilitation as a good way of opening up traditional scalar configurations in order to influence and shift policy agendas. But scalar 
inconsistencies between old and newly configured institutions create tensions and inefficiencies, as river basin actors usually lack implementation power. Despite the prior existence of a relatively powerful river-basin organisation in the Wupper catchment, the district authorities, municipalities and landowners retain de facto powers of veto. Interestingly, therefore, facilitation appears to increase the influence of public authorities, by resolving conflicts of interests across different scales, forcing different departments to develop a common strategy and integrating all the relevant units into the process.

5. Harmonization: Pushing for new common standards on other scales.

This intra- and cross-scalar action uses the opportunity of rescaling the water policy agenda to influence problem definitions and solutions by harmonising standards. We observe this as an important motive of the EU CIS process, designed to provide guidance for common implementation, but also of LAWA's Frauenchiemsee Paper. In both cases, developing common standards across multiple scales is regarded as critical for effective implementation of the WFD. The Wupperverband also pursues this strategy by promoting its own problem-solving techniques as a model for other water boards or government agencies to follow, using its membership of national DWA committees as an avenue of influence. Harmonising standards across multiple scales is a powerful instrument for increasing an actor's influence. The downside is that it demands considerable resources for an actor to get their own methodology etc. accepted as the new standard.

6. Appropriation: Acting scalar to adapt the policy agenda to accommodate other interests.

The prime example of appropriation is the deliberate strategy of the agricultural chamber in NRW to advance farmers' interests by active communication, negotiation and coercion on multiple scales. Cleverly embracing the WFD in principle and setting itself up as a cooperative partner, it is doing so only in so far as this meets agricultural interests, seeking out win-win situations from the WFD implementation process. It is acting intra-scalar by lobbying EU agencies and state ministries, but also cross-scalar through active engagement in river basin planning at the Wupper. To a lesser extent and with less deliberation local stakeholders participating in the round table talks are striving to link river basin management requirements to their own urban/regional development agendas. Appropriation can empower actors equipped with the necessary resources and influence to shape the policy agenda in their interest across multiple scales. This can help veto-players to continue to resist change to the WFD implementation process. Nevertheless, it does require these actors to commit themselves publicly to fulfilling the WFD's political aims.

7. Acquiescence: Accepting the necessity to act scalar.

An interesting type of unintended scalar action can be termed acquiescence, in which scalar practices are adopted where they are unavoidable or opportune. The best example is how, in the process of WFD implementation, the counties are finding themselves in an intermediary position between the NRW government, the Wupperverband and local stakeholders. Given their considerable legal responsibilities for local water policy and the communication problems between the above actors, county officials are becoming unwitting brokers in implementing the WFD in the sub-basin. Their scalar action is distinctly non-strategic by nature. Accepting the necessity to act multi-scalar by these actors nevertheless appears important for advancing cross- and intra-scalar collaboration. Although they never expected to be a key player in the implementation process, several counties are now taking advantage of scalar reconfigurations in the region to strengthen their own position. Acquiescence - and the unexpected engagement which it involves can thereby empower new stakeholders of environmental governance. 


\section{Conclusions}

This paper has investigated the implementation of the WFD as an exemplar of rescaling environmental governance in Europe. In our study of multi-scalar strategies and practices in Germany, focussing on the Wupper sub-basin, we investigated how relevant stakeholders from the local to the European level, from small catchments to large river basins - are acting scalar in implementing the WFD. We selected this sub-basin not as a representative case for Germany as a whole, but as a favourable context for exploring the interaction and shifts between established hydrological and jurisdictional scales during the implementation process.

In response to the first research question posed - relating to modes of multi-scalar action - the general observation is that acting scalar is not the preserve of a few perceptive and resourceful actors. All the actors we studied are acting scalar to some extent, although in very different ways, with different degrees of deliberation and to different effect. This is perhaps not surprising, given the traditional hierarchies and responsibilities of water management in Germany, its federal structure and the cross-boundary nature of water resources management. However, the extent to which the actors are working across multiple scales and the increased intensity of these scalar relations indicates that the WFD has made multi-scalar activity essential for all key actors if they are to fulfil their legal responsibilities, secure their intrinsic interests and strengthen their power base. The empirical analysis revealed great variety in the ways actors are working across scales. Looking beyond a simple binary of scalar strategy vs. scalar practice we developed inductively a typology of multi-scalar action to accommodate and interpret this diversity. The seven types identified are: engagement, enrolment, delegation, facilitation, harmonisation, appropriation and acquiescence. Being founded in the empirical case, these are not set up as universal types, nor are they intended as in any way conclusive. Rather, they are a heuristic for interpreting the case we studied which will, hopefully, be of value in other empirical studies of scalar action in very different settings.

We used this typology to reflect on what kinds of impacts these multi-scalar actions can have. In response to the second and third research questions, we were interested in ascertaining what difference such actions can make not only to power relations, but also to scalar configurations themselves. The first observation is that not all types of scalar action are available to all actors. Some actors are far better positioned to act scalar than others. For instance, the agenda-setting authority of the water unit in DG Environment and the resources available to the agricultural chamber LWK have enabled both organisations to substantially shape policies and practices of river basin management on various scales. For other actors existing scalar configurations can pose constraints on their action, whether multi-scalar or otherwise. The state and district authorities, for example, are so rooted in jurisdictional hierarchies that their scope for cross-scalar action is limited.

The second observation is that the process of implementing the WFD has opened up old scalar configurations of water management planning in Germany, oriented traditionally around hierarchically structured political jurisdictions, enabling a far greater variety and intensity of cross-scalar interaction than in the past, even for the Wupper with its history of basin-based water management. By exploiting this opportunity and practising one or more of the types of scalar action described in this paper, actors can acquire new political leverage over the implementation process. Conversely, the empowerment of certain actors can be at the expense of other actors, who may need to compete for influence previously taken for granted, as experienced by the environmental groups in the Wupper sub-basin. Multi-scalar action can also place considerable demands on organisations if - as in the case of small lobby groups in Brussels - they do not have sufficient resources to reap the potential benefits. Whilst making 
the case for the importance of addressing the politics of scale, we acknowledge that power relations are influenced by (spatial and non-spatial) factors which are not scalar at all and that some multi-scalar practices have only a modest impact on power relations.

The third observation is that the rescaling set in motion by the WFD is not working solely - or even primarily - in favour of actors who are basin-based. Counter to what might be expected, the beneficiaries of multi-scalar action include not just the region's principal river basin organisation, the Wupperverband, but also bodies which are constituted around political jurisdictions, such as the counties and the agricultural chamber. Public authorities at all scales - from local to national - are not simply reacting defensively to shore up the authority of 'their' territorial jurisdictions against a new hydro-technical scalar regime, but are actively engaged in working collaboratively across scales and are developing new avenues of influence - as well as new modes of cross-scalar governance - as a result.

Our final remark is that the case points clearly to the inherent dynamics of scalar politics. Despite the apparent rigidity of both scalar dimensions discussed here - i.e. the federal structure of water governance in Germany on the one hand and the hydrological scales prescribed for water management planning by the WFD on the other - the process of implementing the WFD, although leaving legal responsibilities untouched, is revealing considerable fluidity in the importance and meanings attributed to these scales. The scalar strategies and practices of prominent actors are not simply taking place on or between certain scales, they are redefining and reconstituting the function and significance of these scales. They are even creating new scalar hybrids (cf. Johnson, 2012) at the interface between hydrological and jurisdictional domains. Exploring what this means for the scalar reconfiguration of environmental governance in other fields and in other countries would appear to be a most rewarding topic for future research.

\section{Acknowledgements}

The authors would like to thank the German Research Foundation (DFG) for funding the project RescalE on which this paper is based. We are also very grateful to Nicholas Jager, Jens Newig and Daniel Schulz for their comments on an earlier version of this paper, as well as participants of panels at the IPSA World Congress held in Madrid in July 2012, the WaterScale international symposium in Berlin in March 2013, the NESS Conference in Copenhagen in June 2013 and the ECPR General Conference in Bordeaux in September 2013, where draft versions were presented. We are indebted to Ramona Bunkus for researching some of the material for this paper and to two anonymous reviewers for their valuable suggestions for improvements.

\section{References}

Agnew, J. (1997): The dramaturgy of horizons: geographical scale in the 'Reconstruction of Italy' by the new Italian political parties, 1992-1995. In: Political Geography 16 (2), 99-122.

Baumgartner, F.R.; Jones, B.D. (1993): Agendas and Instability in American Politics. Chicago.

Barnett, M.; Duvall, R. (2005): Power in International Politics. In: International Organization 59, 3975. 
Bernhardt, C.; Hüesker, F. (in press): State-Founded Water Boards in Industrialized Western Germany. In: D. Huitema, S. Meijerink (eds.): The Politics of River Basin Organizations.

Blomquist, W.; Schlager, E.; Heikkila, T. (2004): Common Waters, Diverging Streams: Linking Institutions and Water Management in Arizona, California, and Colorado. Washington DC.

Brenner, N. (2001): The limits to scale? Methodological reflections on scalar structuration. In: Progress in Human Geography 25 (4), 591-614.

Brenner, N. (2004): New State Spaces. Urban Governance and the Rescaling of Statehood. Oxford/New York.

Bulkeley, H. (2005): Reconfiguring environmental governance: Towards a politics of scales and networks. In: Political Geography 24, 875-902.

Deutscher Naturschutzring (2012): Ping-Pong Europapolitik. Umweltorganisationen an der Schnittstelle zwischen Berlin und Brüssel. DNR-Themenheft II.

Dore, J.; Lebel, L. (2010): Deliberation and Scale in Mekong Region Water Governance. In: Environmental Management, 46, 60-80.

European Commission (2012): A Blueprint to Safeguard Europe's Water Resources. European Commission, Brussels. COM (2012) 673 final.

European Community (EC) (2000): Directive 2000/60/EC of the European Parliament and of the Council of 23 October 2000 establishing a framework for Community action in the field of water policy. In: Official Journal of the European Communities, 22.12.2000, L 327/1-72.

European Environmental Bureau (ed.) (2011): An Assessment of actions taken by the EU to Implement the Water Framework Directive (WFD) Do they make the WFD work? Brussels.

Gualini, E. (2006): The Rescaling of Governance in Europe: New Spatial and Institutional Rationales. In: European Planning Studies 14 (7), 881-904.

Hay, C. (1997): Divided by a Common Language: Political Theory and the Concept of Power. In: Politics 17 (1), 45-52.

Herrfahrdt-Pähle, E. (2014): Applying the concept of fit to water governance reforms in South Africa. In: Ecology and Society 19 (1).

Heeg, S. (2008): Die Europäische Union - eine fragile Staatlichkeit? Politisch-territoriale Organisation der EU und die Diskussion um Scale. In: M. Wissen, B. Röttger, S. Heeg (eds.): Politics of Scale. Räume der Globalisierung und emanzipatorischer Politik, Münster, 251-266.

Huitema, D.; Bressers, J. (2006): Scaling water governance: the case of the implementation of the European Water Framework Directive in the Netherlands (available at http://www2.bren.ucsb.edu/ idgec/papers/David_Huitema.pdf).

Jager, N.; Hüesker, F.; Newig, N.; Moss, T.; Grund, W. (forthcoming): Analysing Scale in Environmental Governance: The case of water governance in Europe.

Johnson, C. (2012): Toward Post-Sovereign Environmental Governance? Politics, Scale, and EU Water Framework Directive. In: Water Alternatives 5(1), 83-97.

Jones, Katherine (1998): Scale as epistemology. In: Political Geography 17 (1), 25-28.

Kaika, M.; Page, B. (2003): The Water Framework Directive: A New Directive for a Changing Social, Political and Economic European Framework. In: European Planning Studies 11 (3).

Kastens, B.; Newig, J. (2007): The Water Framework Directive and agricultural nitrate pollution: Will great expectations in Brussels be dashed in Lower Saxony? In: European Environment 17 (4), 231-246.

Kastens, B.; Newig, J. (2008): Will participation foster the successful implementation of the water framework directive? The case of agricultural groundwater protection in northwest Germany. In: Local Environment 13 (1), 27-41. 
Köhler, B. (2008): Die Materialität von Rescaling-Prozessen. Zum Verhältnis von politics of scale und political ecology. In: M. Wissen, B. Röttger, S. Heeg (eds.): Politics of Scale. Räume der Globalisierung und emanzipatorischer Politik. Münster, pp. 208-223.

LAWA Thesenpapier (2010): Flussgebietsbewirtschaftung in Deutschland (Frauenchiemsee Paper).

Lebel, L.; Garden, P.; Imamura, M. (2005): The Politics of Scale, Position, and Place in the Governance of Water Resources in the Mekong Region. In: Ecology and Society, 10 (2), art. 18.

Moss, T. (2004): The governance of land use in river basins: prospects for overcoming problems of institutional interplay with the EU Water Framework Directive. In: Land Use Policy 21, 85-94.

Moss, T.; Newig, J. (2010): Multilevel Water Governance and Problems of Scale: setting the Stage for a Broader Debate. In: Environmental Management (46), 1-6.

Newig, J. (2007): Does public participation in environmental decisions lead to improved environmental quality? In: CCP 1, 51-71.

Newig, J.; Fritsch, O. (2009): Environmental Governance: Participatory, Multi-Level - and Effective? In: Environmental Policy and Governance (19), 197-214.

Nohlen, D.; Schultze, R.-O. (eds,) (1995): Lexikon der Politik. Band 1. Politische Theorien. München.

Norman, E.; Bakker, K.; Cook, C. (2012): Introduction to the Themed Section: Water governance and the politics of scale. In: Water Alternatives 5(1), 52-61.

Reed, M.; Bruyneel, S. (2010): Rescaling environmental governance, rethinking the state: A threedimensional review. In: Progress in Human Geography 34 (5), 646-653.

Schmid, C. (2003): Raum und Regulation. Henri Lefebvre und der Regulationsansatz. In: U. Brand, W. Raza (eds.): Fit für den Postfordismus? Theoretisch-politische Perspektiven des Regulationsansatzes. Münster, pp. 217-242.

Smith, N. (2000): Scale. In: R.J. Johnston; D. Gregory; G. Pratt; M. Watts (eds.): The Dictionary of Human Geography. Oxford, 724-727.

Smith, N. (2008): Uneven development. Nature, capital, and the production of space. $3^{\text {rd }}$ edition $\left[1^{\text {st }}\right.$ edition 1984]. Athens.

Swyngedouw, E. (1997): Neither Global nor Local. "Glocalization" and the Politics of Scale. Spaces of Globalization. Reasserting the Power of the Local. New York/London, 137-166.

Swyngedouw, E. (2000): Authoritarian governance, power, and the politics of rescaling. In: Environment and Planning D: Society and Space 18, 63-76.

Swyngedouw, E. (2001): Scaled Geographies: Nature, Place, and the Politics of Scale. Oxford.

Swyngedouw, E. (2007): TechnoNatural Revolutions - the Scalar Politics of Franco's Hydro-Social Dream for Spain 1939-1975. In: Transactions, Institute of British Geographers 32 (1), 9-28.

Swyngedouw, E. (2010): Place, Nature and the Question of Scale: Interrogating the Production of Nature. Discussion Paper 5. Berlin-Brandenburgische Akademie der Wissenschaften.

Thiel, A. (2009): Europeanisation and the Rescaling of Water Services: Agency and State Spatial Strategies in the Algarve, Portugal. In: Water Alternatives 2 (2), 225-244.

Thiel, A. (2010): Constructing a Strategic, National Resource: European Policies and the Up-Scaling of Water Services in the Algarve, Portugal. In: Environmental Management 46 (1), 44-59.

Uitermark, J. (2002): Re-scaling, 'scale fragmentation' and the regulation of antagonistic relationships. In: Progress in Human Geography 26 (6), 743-765.

Woods, D. (2008): Stakeholder involvement and public participation: a critique of Water Framework Directive arrangements in the United Kingdom. In: Water and Environment Journal 22, 258-264.

\section{List of interviews}


Agricultural Chamber of North-Rhine Westphalia, Essen, August 2012 (interview LWK).

Committee of Professional Agricultural Organisations/General Committee for Agricultural Cooperation in the European Union (COPA-COGECA), Brussels, February 2012 (interview EU agriculture).

District Government of Düsseldorf, Environmental Department, Düsseldorf, May 2012 (interview district government).

European Commission, Environment Directorate-General, Unit C.1 Water, Brussels, September 2011 (interview DG ENV).

European Environmental Bureau (EEB), Brussels, February 2012 (interview EU environment).

European Federation of National Associations of Water Services (EUREAU), Brussels, February 2012 (interview EU water utility).

Forestry Association North-Rhine Westfalia, District Group Rhein-Berg-Leverkusen, Leverkusen, February 2012 (interview local agricultural association).

German State of Lower Saxony, Ministry for the Environment, Energy and Climate Protection (Niedersächsisches Ministerium für Umwelt, Energie und Klimaschutz, Hannover, November 2011 (interview Lower Saxony).

German State of Hesse, Ministry for the Environment, Energy, Agriculture and Consumer Protection, Wiesbaden, February 2012 (interview Hessen).

German State of North-Rhine Westphalia, State Agency for Nature, Environment and Consmumer Protection, Bonn, August 2012 (interview LANUV).

Oberbergischer County, Unit for Environmental Protection, Gummersbach, May 2012 (interview county 1).

Remscheid City, Environmental Unit, Remscheid, May 2012 (interview municipality).

Rheinisch-Bergischer County, Unit for Environmental Protection, Bergisch Gladbach, August 2012 (interview county 2).

Symposia Wupperverband: Annual public symposium on current issues of river basin management in the Wupper basin, participated in 2011, 2012, 2013, Stadthalle Wuppertal (for detailed information check www.wupperverband.de).

Water Supply Association Rhein-Wupper, Wermelskirchen, February 2012 (interview local water utility).

Workshops Wupperverband: Three internal workshops with leading representatives of Wupperverband were held in 2011, 2012 and 2013. 